\title{
Farming Practices Adopted for Organic Production of Alfalfa as a Forage Legume in UAE for Animal Feed Applications
}

\author{
Khalil Ur Rahman*, Mohamed Khalifa Bin Thaleth and Khalifa Rashid AlTeneiji \\ Al Nakhli Sector, Dubai, UAE
}

*Corresponding author: Khalil Ur Rahman, Al Nakhli Sector, Dubai -Hatta Road, Dubai, UAE

\begin{tabular}{lll}
\hline ARTICLE INFO & & ABSTRACT \\
\cline { 1 - 1 } $\begin{array}{l}\text { Received: } \\
\text { Published: August 17, } 2020\end{array}$ & $\begin{array}{l}\text { Citation: Khalil Ur R, Mohamed Khalifa Bin T, Khalifa Rashid AlTeneiji. Farming Practices } \\
\text { Adopted for Organic Production of Alfalfa as a Forage Legume in UAE for Animal Feed } \\
\text { Applications. Biomed J Sci \& Tech Res 29(5)-2020. BJSTR. MS.ID.004853. }\end{array}$
\end{tabular}

\section{Introduction}

Alfalfa is one of the forage crops widely cultivated due to its adaptability on different soil and environmental conditions. This forage crop is cultivated in more than 80 countries with over 210 million tons of alfalfa hay produced. Alfalfa is highly nutritious for use as animal feed due to its high protein content and easier digestibility. The soils of the UAE are dominantly sandy and infertile and hence show poor physical, chemical and fertility properties, suggesting frequent irrigation and replenishment nutrients based on crop requirement. Among other forages alfalfa is grown in many farms. Alfalfa is salt sensitive crop (threshold salinity $2 \mathrm{dS} / \mathrm{m}$ ) and could not tolerate high water salinity levels which are the general case of most of the agricultural farms in the UAE. Alfalfa plays an important role in the feeding of Camels, dairy cows, cattle, horses, sheep and goats. It has highest feeding value of all common hay crops and is rich in protein, calcium, various minerals, B vitamins and vitamins C, D, E and K. Alfalfa biomass can be processed into silage for long term applications. The alfalfa green matter yield varies from 75 to 100 tha- 1 and 15 to 20 tha- 1 dry matter yields.

Perennial legumes such as alfalfa with rapid recovery after cutting, longevity and tolerance to environmental stress are important for stable yield. The symbiotic N2 fixation in alfalfa eliminates the need for chemical $\mathrm{N}$ and adds a beneficial carryover effect in crop rotation. The well-developed root system on alfalfa in the second to the third year of growth help provide an equivalent application of 40-60t of manure in terms of the content of nitrogen, phosphorus, potash and other element. Factors which affect alfalfa hay quality include, growing conditions, harvesting, handling, storage, fertility, varieties, pests and presence of other plant species. We utilize advanced irrigation technology to maximize alfalfa forage quality and yields while conserving water resources. The ability to control biomass quality, seed types and harvest schedules help better animal health and productivity. The demand for alfalfa forage for animal feed is continuing to grow in the United Arab Emirates and the locally produced alfalfa will help reduce import of the forage biomass and meet the stringent quality control for animal feed for dairy and animal productivity. It is to be noted that a comparison between crop yield from organic and conventional cannot be compared, due to the use of heavy chemicals in the latter case. However, there are various options if properly adopted the health of sandy soils can be improved through enhancing soil quality using natural soil amendments and adopting $4 \mathrm{R}$ nutrient stewardship as well as seed inoculation with rhizobium and mycorrhiza application. Growing alfalfa locally have two very clear benefits compared to imported ones, that is, control on the quality of alfalfa forage- saving of financial resources with less import and ready availability of fresh fodder without hay making. Despite the success of the green revolution, poverty and hunger remained major challenges in many parts of the world, particularly in developing countries located in the dry lands with unprecedented population 
rise. Global population which was 0.6 billion in 1700 has increased to 7.2 billion in 2015 and 10.9 billion is projected by 2100. This shows that with population growth the global demand for food, forage and fuel will increase leading to over exploitation of land and water resources to gain more benefits and this will accelerate land degradation and destruction of the environment [1]. The very first status of the world's soil resource report has already alarmed that "the majority of the world's soil resources are in only fair, poor or very poor conditions and that conditions are getting worse in far more cases than they are improving [2]. Despite the land resources are at high threats of degradation and considering the population growth it has been projected that by 2050 , agricultural production must increase by $60 \%$ globally-and by almost $100 \%$ in developing countries - to meet food demand alone.

Owing to the dry land conditions and geographic location the UAE receives scanty rainfall insufficient to recharge the aquifer, so there is imbalance between water abstraction and recharge resulting into fast depletion of water resources and increase of water salinity. The high salinity reduces the choices for crop selection; therefore, growing cereals (wheat, rice) in the open field is not viable option. However, under such conditions forages (sorghum, pear millet, and barley) can be grown by irrigation with saline water based on the salinity tolerance (threshold) level and following leaching requirement concept. Alfalfa (Medicago Sativa) is salt-sensitive crop, but if water salinity can be reduced to match its salt tolerance level or irrigation with fresh water, alfalfa can be grown in desert environment through using best soil, water and crop management practices [3].

\section{Alfalfa (Medicago sativa)}

It is the most important forage crop in the world due to its high yield, nutritional quality, high crude protein (CP) content and its adaptability to a wide range of soil and climatic conditions [4]. Alfalfa is a perennial forage legume crop. It is used for grazing, hay, silage as well as green manure and cover crop; it is used less frequently as pasture. Being perennial alfalfa crop normally lives four to eight years depending upon the environment and potential of the variety. Once seedlings are established through small-seeds the plants can reach up to height of 1-2 feet along with deep root system (+2meters) with unrestricted good soil substratum. Alfalfa initially grows slowly, after several months hard crowns are established that contain shoot buds enabling alfalfa to regrow many times after being harvested. Alfalfa when grown on soils where it is well-adapted, alfalfa is often the highest-yielding forage plant, but its primary benefit is the combination of high yield per hectare and high nutritional quality.

Like other legumes, its root nodules contain bacteria Sinorhizobium meliloti with the ability to fix atmospheric nitrogen, producing a high-protein feed regardless of available nitrogen in the soil. Its nitrogen-fixing ability (which increases soil nitrogen) and its use as an animal feed greatly improve agricultural efficiency. Alfalfa grows well on well-drained soils with a neutral pH of 6.8-7.5. Soils low in fertility should be fertilized with manure or a chemical fertilizer, but correction of $\mathrm{pH}$ is particularly important. Alfalfa is cut six to eight times a year. Total yields are typically around eight tons per hectare in temperate environments, but yields have been recorded up to 20t/ha. Yields vary with region, weather, and the crop's stage of maturity when cut. Later cuttings improve yield, but with reduced nutritional content.

\section{Constraints and Viable Options to Improve Alfalfa Production}

Alfalfa plant exhibits auto-toxicity which means it is difficult for alfalfa seed to grow in existing stands of alfalfa. Therefore, alfalfa fields are recommended to be rotated with other species (other potential crops, like maize, sorghum, pearl millet, grasses etc) before reseeding. Low seed rates used, usually a seeding rate of $15-22 \mathrm{~kg} /$ hectare is recommended, with differences based upon region, soil type, and seeding method. Harvesting the alfalfa by mowing the entire crop area destroys the soil biology, but this can be avoided by mowing in strips so that part of the growth remains. Wet soils create conditions suitable for diseases that may kill seedlings, reduce forage yield, and kill established plants. High $\mathrm{pH}$ of soil disturb the nutritional disturbance due to precipitation of phosphorous and micronutrients. Insufficient inoculum in soil reduces nodulation and nitrogen fixation. Another limitation to crop growth is poor drainage, soil with hard pan within potential rooting zone $(1 \mathrm{~m})$ of alfalfa. Poor soil drainage also reduces the movement of soil oxygen to roots while uneven soil leads to low spots where water stands and creates patchy water logging. The weeds if not controlled before seeding, these weeds may re-establish faster than the new alfalfa seedlings and reduce stand density.

Used, usually a seeding rate of $13-20 \mathrm{~kg} / \mathrm{hectare}$ is recommended, with differences based upon region, soil type, and seeding method. Harvesting the alfalfa by mowing the entire crop area destroys the soil biology, but this can be avoided by mowing in strips so that part of the growth remains. Wet soils create conditions suitable for diseases that may kill seedlings, reduce forage yield, and kill established plants. High $\mathrm{pH}$ of soil disturb the nutritional disturbance due to precipitation of phosphorous and micronutrients. Insufficient inoculum in soil reduces nodulation and nitrogen fixation. Another limitation to crop growth is poor drainage, soil with hard pan within potential rooting zone $(1 \mathrm{~m})$ of alfalfa. Poor soil drainage also reduces the movement of soil oxygen to roots while uneven soil leads to low spots where water stands and create patchy waterlogging. The weeds if not controlled before seeding, these weeds may re-establish faster than the new alfalfa seedlings and reduce stand density. 


\section{References}

1. Egamberdieva GME, Albacete A Martýnez-Andujar C, Acosta M, RomeroAranda R, Dodd IC, et al. (2008) Hormonal changes during salinityinduced leaf senescence in tomato (Solanumly copersicum L.) J. Exp. Bot 59: 3039-3050.

2. (2015) FAO-ITPS. Status of the World's Soil Resources (SWSR).

ISSN: 2574-1241

DOI: $10.26717 /$ BJSTR.2020.29.004853

Khalil Ur Rahman. Biomed J Sci \& Tech Res

(c) (P) This work is licensed under Creative

Submission Link: https://biomedres.us/submit-manuscript.php
3. Technical Summary. Food and Agriculture Organization of the United Nations and Intergovernmental Panel on Soils, Rome, Italy.

4. Howieson J, Ballard R (2004) Optimizing the legume symbiosis in stressful and competitive environments within southern Australia: some contemporary thoughts. Soil Biology and Biochemistry 36(8): 1261-1273.

$\begin{array}{ll}\text { BIOMEDICAL } & \text { Assets of Publishing with us } \\ \text { RESEARCHES } & \text { - Global archiving of articles } \\ \text { - Immediate, unrestricted online access } & \text { - Rigorous Peer Review Process } \\ & \text { - Authors Retain Copyrights } \\ & \end{array}$

